\title{
Effect of Internal Control on Financial Performance of Firms in Nigeria. (A Study of Selected Manufacturing Firms)
}

\author{
Eniola, Omoniyi Jacob ${ }^{1}$ 'Akinselure, Oluwafemi Philip ${ }^{2}$ \\ Lecturer, Department of Accounting, Joseph Ayo Babalola University, Ikeji-Arakeji, P.M.B 5006, llesa, Osun State, Nigeria. \\ Phd Student, Department of Accounting, Joseph Ayo Babalola University, Ikeji-Arakeji,Osun State.
}

\begin{abstract}
This study focuses on the effect of internal control on financial performance of some selected firms. The methodology of the study is based on survey research approach. The statistical data used for the study were obtained by distribution of one hundred and fifty (150) questionnaire among selected employees, in the five (5) organisations considered in this research work. These respondent were selected using non-probability sampling method, the data obtained from the questionnaire were analysed using multiple regression statistical tools in SPSS ( Statistical packages for social sciences.). The result of the analysis shows that internal control has significant relationship with fraud perpetrated in the organization, and this was because the P-value obtained (i.e.0.002) using multiple regression was greater than the benchmark value of 5\% specified in SPSS for this analysis. Based on this result, the study recommends that management should develop more effective strategies that will ensure that internal control is effective and efficient, so that fraud perpetration in the organisation will be significantly reduced.
\end{abstract}

\section{Introduction}

The survival of any organisation depends on the effective and efficient utilisation of resources (financial and non-financial)at the disposal of the organisation. Hence, to optimize the utilisation of resources entrusted to all employees in an organisation, various form of control are put in place by management of the organisation, among these major controls are internal control and internal audit to mention a few. According to Kirsch,(2002)Internal control can be defined as a set of mechanism designed to motivate an individual or a group towards achievement of a desired objectives while, Ouchi (1979) stated that internal control must be able to achieve the objective of bringing about cooperation among people with divergent objectives in an organisation. Similarly, International Standard on Auditing (ISA 400) defines internal control as all policies and procedure adopted by the management of an entity to assist in achieving the primary objectives of the management by make sure the business is conducted in the most possible efficient way and also ensuring strict adherence to management policies, safeguarding of asset, prevention and detection of fraud and timely preparation of reliable account. On the other hand, Financial Performance of an organization can be described in various form, such as; return on assets, return on sales, return on equity, return on investment, return on capital employed and sales growth (Gerrit\&Abdolmohammadi, 2010). It is also a measure of the excess value a company has provided to its shareholders over the total amount of their investments. According to Donald \&Delno (2009), appropriate performance measures are those which enable organizations to direct their actions towards achieving their strategic objectives.

\subsection{Statement of the Problems}

Despite the fact that internal control system have been in existence for many years in most organisation, the problem of financial crimes, have continued to be on the increase. Examples of this financial crimes include; financial irregularities within the departments, collusion among senior or highly-trusted employees, breaches of control, to mention a few. Various researchers, have affirmed that internal control set by management in most organisation has not been able to completely prevent these fraudulent occurrences because these controls have not significantly reduced the reoccurring fraud and corruption perpetuated by employees in most organizations.

\subsection{Objectives of the Study}

The main objective of this research work is to examine the impact of internal control on financial performance in selected manufacturing firms while the specific objectives are to:

- ascertain if internal control has relationship with fraud perpetration in the organisation.

- examine the relationship that exist between internal control and attainment of the organisation objectives 


\subsection{Conceptual Framework}

\section{Literature Review}

\subsubsection{Definition of Internal Control}

Internal control can be defined as a set of mechanism designed to motivate an individual or a group towards achievement of a desired objectives (Kirsch, 2002). Ouchi (1979) was of the view that internal control must be able to achieve the objective of bringing about cooperation among people with divergent objectives in the organisation. Furthermore, Cahill (2006) defines internal control as a system of internal administrative efficiency which often leads to design of a system that will enhance financial check and balance which will support corrective actions intended by the management of the organisation and will ensure the primary goal of the organisation is achieved.

Similarly, Transparency International (2006) reported that internal control are control developed by organisation to generate transparency and avoid corruption. Transparency International (2006) further stated that corruption usually arise as a result of abuse of public office for private gains. Examples includes; Bribery: kickbacks and embezzlement of public funds. International Standard on Auditing (ISA 400) defines internal control as all policies and procedure adopted by the management of an entity to assist in achieving the primary objectives of the management by ensuring that the business is conducted in the most efficient way possible and also ensuring strict adherence to management policies, safeguarding of asset, prevention and detection of fraud and timely preparation of reliable account records.

\subsubsection{Impact of Internal Control on Financial Institution}

Looking at financial institution for example a bank it is always under the control of some bodies like CBN, SEC etc. these bodies monitor and influence the activities of all banks directly or indirectly. It has been established that fraud is a very deadly disease to any commercial banks, because if allowed to grow and eat deep into the banking system, it inevitably leads to distress. Evidence from recent banks regarding fraud and forgeries in commercial and merchant banks reveals that the phenomenon has been on the upward trend,i.e the incidents of fraud and forgeries has been increasing, despite the control measures put in place by individual banks. The subject fraud has increasingly gained the attention of the monetary and supervisory authorities, in view of the fact that fraud results in huge financial losses to banks and their customers loss of confidence in banks which may ultimately bring about bank failure. It is therefore important to stress the need for all banks to comply with the statutory requirements of rendering returns for the effectiveness of all policy measures, which the monetary and supervisory authorities might design to curb this menace. The statutory requirement for financial institution is to employ external auditors to check their books and affairs. regulatory authorities exercise their powers to deal with members of the institution and management found to have grossly violated the regulatory and statutory code of conduct or to have been engaged in financial malpractice or have condoned such offences of other staff.

\subsection{Theoretical Framework}

\subsubsection{Stakeholder's Theory}

According to Fredman (2004) stakeholder theory emphasizes that some individual or group are very important for the survival of the organisation. This explanation is seen as organisation oriented explanation, but in an earlier research Fredman reported that stakeholder theory refers to any group or individual who can affect or who is likely to be affected by the achievement of the organisation objective. Friedman (2009) supported these in his definition of the stakeholders theory was more balance and covers a wider area than those of theStanford Research Institute (SRI) (1963) which defined the theory simply as those people who, without their support and ideas, the organisation would not exist. They further stated that Fredman definition was wider because it included individuals outside the firm and other groups that may consider themselves as the stakeholders in the organisation without the firm acknowledging them to be so. The stakeholders in most organizations usually include shareholders, employees, customers, lenders, suppliers, local charities and interest group etc.

\subsubsection{Stewardship Theory}

Davis, Schoorman and Donaldson (1997) define stewardship theory as the process where stewards protect and maximize shareholders wealth through improved firm's performance, because by doing so, the stewards recorgnise, that his utility function is maximized. This, stewardship theory refers more to the manager and chief executive as the main individual responsible for the stewardship function in the organisation. In another, definition, Block (1996) reported that the stewardship role is depicted with service to the firm over self interest, he further established that organisation and individual role can be easily achieved by honouring the stewardship relationship and treating followers like owners and partners. 


\subsubsection{Institutional Theory}

According to Williamson (1985), institutional theory emphasises that without institutions and markets, firm existence would have been impossible and transaction could never have begun. Conventionally, institutions are defined as what people regard or do not regard as acceptable and which often form the framework in which any action finds its legitimacy. Similarly, Karishna and Das (2005) made similar conclusion, in their study, when they established that the environment often recorgnise and empower institution to award firm or withdraw from firm resources such as legitimacy. Institutional tenets are usually achievable when the business complies strictly with high level of regulations. This theory also emphasized that organisation are not just places were goods and services are produced but are also custodian of social and cultural system. A major researcher on the institutional theory is Dimaggio and Powell (1983) who define institutional theory as those organisation that are in aggregate, constitute a recognised area of the institutional Life. These organisations includes Key suppliers,

\subsection{Empirical Framework}

\subsubsection{Determinants of Financial Performance of Manufacturing Firms}

Dixon et al (1990) said that appropriate performance measures are those which enable organizations to direct their actions towards achieving their strategic objectives. Kotey, Reid and Ashelby (2002) contend that performance is measured by either subjective or objective criteria, arguments for subjective measures include difficulties with collecting qualitative performance data from small firms and with reliability of such data arising from differences in accounting methods used by firms. Whittington and Kurt (2001) found out that the objective performance measures include indicators such as profit growth, revenue growth, return on capital employed. Financial consultants Stern Stewart and Co. created Market Value Added (MVA), a measure of the excess value a company has provided to its shareholders over the total amount of their investments (John and Morris, 2011). This ranking is based on some traditional aspects of financial performance including: total returns, sales growth, profit growth, net margin, and return on equity. Dwivedi (2002) however, mentions other financial measures to include value of long-term investment, financial soundness, and use of corporate assets. John and Morris (2011) mentions accounting based performance using three indicators: return on assets (ROA), return on equity (ROE), and return on sales (ROS). Each measure is calculated by dividing net income by total assets, total common equity, and total net sales, respectively. Mawanda (2008) conducted a research on effects of internal control systems on financial performance in institution of higher learning Uganda. In his study he investigated and sought to establish the relationship between internal control systems and financial performance in an Institution of higher learning in Uganda. Internal controls were looked at from the perspective of Control Environment, Internal Audit and Control Activities whereas Financial performance focused on Liquidity, Accountability and Reporting as the measures of Financial performance. The Researcher set out to establish the causes of persistent poor financial performance from the perspective of internal controls. The study established a significant relationship between internal control system and financial performance. The investigation recommends competence profiling in the Internal Audit department which should be based on what the University expects the internal audit to do and what appropriate number staff would be required to do this job. The study therefore acknowledged role of internal audit department to establish internal controls which have an effects on the financial performance of organizations.

\section{Methodology}

The methodology of this study is based on survey research approach, which involves distributing specific number (i.e.150) of questionnaires to selected number of employees in the firms considered in this study. These firms are Guinness Nig, Plc, PZ Nig. Ltd, Dangote Cement Plc,WapcoPlc and Beta glass Nig, Plc..These companies were chosen based on the sampling method (i.e. purposive sampling method) adopted by the study. The results obtained from the questionnaires wereanalyzed using regression analysis in SPSS (Statistical Package for social sciences).

\subsection{Model Specification}

The model specification used in this study is based on the explanation of the relationship between the dependent and independent variable of this research work.

Therefore, the multiple linear regression equation for this study is defined as:

$Y=\beta_{0}+\beta_{1} x_{1}+e$---------o- (1)

$\mathrm{Y}=\mathrm{f}(\mathrm{X})$

Where, $\mathrm{Y}=$ the Dependent variable, which was represented by Financial performance

$\mathrm{X}_{1}=$ Independent variables, which was represented by Internal Control

$\beta_{0}$ represents the intercept or constant

$\beta_{1}$ represents the regression parameters/ regression coefficient $\mathrm{e}=$ Error term. 


\subsection{Data Analysis and Interpretation. \\ 4.1 Introduction}

This chapter is on the presentation, analysis and interpretation of the data collected from respondents of the selected organisation. The responses of the respondents were basically categorised into three, and this three constitute the variables that were used in generating the finding for this study. The analyses of the questionnaire were done using multiple regression analysis in SPSS (Statistical package for social sciences).

Table 4.2.1 Rate of Respondents

Source: Field Survey, 2016

\begin{tabular}{|l|l|l|l|}
\hline & Frequency & Valid Percent & Cumulative Percent \\
\hline Valid Returned & 110 & 73.3 & 73.3 \\
\hline Unreturned/Missing & 40 & 26.7 & 100.0 \\
\hline Total & 150 & 100 & \\
\hline
\end{tabular}

The above tables shows that One hundred and fifty (150) copies of the questionnaire were printed and distributed, but only One hundred and ten (110) were returned, while the remaining, were either missing orunreturned, The missing and unreturned ones amounted to forty(40). The reasons for the unreturned and missing questionnaires includes the following.

1. Some respondents misplaced the questionnaires given to them.

2. Some respondents filled the questions wrongly, majorly because they did not read them carefully before answering them, therefore, the researcher had to cancel them and give them another one.

3. Few respondents ticked two answers for a question and this was recorded as void or missing to avoid incorrect interpretation.

\subsection{Hypotheses Testing}

Decision Rule: Accept Null hypothesis if the P-Value obtained using SPSS is greater than 0.05 which is the alpha level of significance specified in SPSS for this Analysis. But, if, otherwise, then accept the Alternate Hypothesis.

Hypothesis One

$\mathrm{Ho}_{1}$ : There is no relationship between internal control and fraud perpetration in the organisation.

Table 4.1 Model Summary

\begin{tabular}{|l|l|l|l|l|}
\hline Model & $\mathrm{R}$ & R Square & Adjusted R Square & $\begin{array}{l}\text { Std. Error of the } \\
\text { Estimate }\end{array}$ \\
\hline 1 & 0.901 & 0.811 & 0.049 & 4.08164 \\
\hline \multicolumn{5}{|l|}{} \\
\hline
\end{tabular}

\section{Model Testing and Interpretation}

The model summary above explains the percentage of the dependent variable (i.e. fraud perpetrated), that can be determined by the independent variable (i.e. internal control). According to this Table, the dependent variables account for $81.1 \%$ (R Square, 0.811) of the independent variable. While the remaining $18.9 \%$ can be explained by other factors outside the scope of this model. This implies that fraud perpetration and internal control have significant relationship with each other. This Pearson correlation coefficient (R) result also showed a positive value of 0.901 , which also lends credence to the fact that fraud perpetration has direct influence on internal control.

Table 4.2 ANOVA

\begin{tabular}{|l|l|l|l|l|l|l|}
\hline Model & Sum of Squares & Df & Mean Square & F & Sig. \\
\hline \multirow{3}{*}{} & Regression & 58.539 & 1 & 58.539 & 3.514 & $0.002^{\mathrm{a}}$ \\
\cline { 2 - 8 } & Residual & 799.668 & 48 & 16.660 & & \\
\cline { 2 - 7 } & Total & 858.207 & 49 & & & \\
\hline
\end{tabular}

The study also conducted ANOVA (i.e. analysis of variance) to determine the extent to which the Independent and dependent variable relates with each other, and the result showed that P- value Obtained (i.e.is 0.002) was lower than the 5\%level of significance specified in SPSS software for this analysis, therefore, according to the decision rule, the Alternate hypothesis will be accepted, while the Null hypothesis will be rejected. This implies that fraud perpetration has significant influence on internal control of the selected organisation.

Table 4.3 Regression analysis

\begin{tabular}{|l|l|l|l|l|l|l|}
\hline \multicolumn{2}{|l|}{ Model } & \multicolumn{2}{|l|}{$\begin{array}{l}\text { Unstandardized } \\
\text { Coefficients }\end{array}$} & $\begin{array}{l}\text { Standardized } \\
\text { Coefficients }\end{array}$ & t & \multirow{2}{*}{} \\
\cline { 3 - 5 } \multicolumn{2}{|l|}{} & B & Std. Error & Beta & & \\
\hline \multirow{2}{*}{1} & (Constant) & 1.539 & 0.791 & & 1.946 & 0.004 \\
\cline { 2 - 6 } & $\begin{array}{l}\text { Self Assessment } \\
\text { scheme }\end{array}$ & $8.619 \mathrm{E}-8$ & 0.000 & 0.261 & 1.875 & 0.002 \\
\hline
\end{tabular}


Multiple Regression analysis was also conducted to determine if the result established by ANOVA Statistic are similar to that of the regression coefficient. The result shows that the P-value obtained(i.e. 0.002) for the regression coefficient was also lower than the alpha level of significance of 5\% specified in SPSS for this analysis therefore, thus, it can be inferred from this result, that the ANOVA Statistic is similar to that of the regression coefficient. Thus, the Alternate Hypothesis will be accepted while the Null Hypothesis will be rejected, which means that there is significant relationship between fraud perpetration and internal control of the organisation.

\section{Hypothesis Two}

$\mathrm{Ho}_{2}$ : There is no relationship between internal control and attainment of organisation objectives.

\begin{tabular}{|l|l|l|l|l|}
\hline Model & R & R Square & Adjusted R Square & Std. Error of the Estimate \\
\hline 1 & 0.782 & 0.612 & 0.021 & 7.66231 \\
\hline
\end{tabular}

\section{Model Testing and Interpretation}

The model summary above explains the percentage of the dependent variable (i.e.organisation objectives) that can be determined by the independent variable (i.e. internal control). According to this model summary, the independent variables account for $61.2 \%$ (R Square, 0.612) of the dependent variable, While the remaining $38.8 \%$ can be explained by other factors outside the scope of this model, this implies that the relationship between the dependent and independent variables is statistically significant, thus any change in internal control will also affect the attainment of the organisation objectives. Also, the Pearson correlation coefficient $(\mathrm{R})$ result also showsthat positive value of 0.782 , which also support the fact that both variables have direct influence on each other..

Table 4.5 ANOVA

\begin{tabular}{|l|l|l|l|l|l|l|}
\hline Model & Sum of Squares & Df & Mean Square & F & Sig. \\
\hline \multirow{4}{*}{1} & Regression & 0.303 & 1 & 0.303 & 0.005 & 0.000 \\
\cline { 2 - 7 } & Residual & 2818.131 & 48 & 58.711 & & \\
\cline { 2 - 7 } & Total & 2818.434 & 49 & & & \\
\hline
\end{tabular}

The study also conducted ANOVA (i.e. analysis of variance) to determine if the result of the model summary above can be relied upon and the result established that P-value obtained(i.e.,0.000) was lower than the alpha level of 5\% specified in SPSS for this analysis, therefore, according to the decision rule, the Alternate hypothesis will be accepted while the Null hypothesis will be rejected. This implies that internal control has significant impact on attainment of organisation objectives. Thus, any effort by the management to enhance internal control will have a multiplier positive effect on achievement of the organisation objectives.

Table 4.6 Regression analysis

\begin{tabular}{|l|l|l|l|l|l|l|}
\hline \multicolumn{2}{|c|}{ Model } & \multicolumn{2}{|l|}{ Unstandardized Coefficients } & $\begin{array}{l}\text { Standardized } \\
\text { Coefficients }\end{array}$ & T & Sig. \\
\cline { 3 - 7 } \multicolumn{2}{|l|}{} & B & Std. Error & Beta & & \\
\hline \multirow{2}{*}{1} & (Constant) & 6.973 & 1.485 & & 4.695 & 0.012 \\
\cline { 2 - 7 } & Tax Audit & $6.205 \mathrm{E}-9$ & 0.000 & 0.010 & 0.072 & 0.000 \\
\hline
\end{tabular}

Multiple Regression analysis was also conducted to determine if the result shown in ANOVA Statistic is statistically correct,.and the result shows that the P-value obtained (i.e.0.000) for the regression coefficient was also lower than the alpha level of significance of 5\% specified in SPSS for this analysis, therefore, it can be inferred from this result, that the ANOVA Statistic was correct. Thus, the Alternate Hypothesis will be accepted while the Null Hypothesis will be rejected, which means that there is significant relationship between attainment of organisation objectives and internal control of the selected organisation.

\section{Discussion of the result}

The findings of this study shows that internal control has significantly relationship with fraud perpetration, this was confirmed by the result of the statistical analysis which shows that that the P-value obtained (0.002) was lower than significance value of 5\% specified in SPSS for this analysis, Furthermore, the study also established that internal control contributes significantly to attainment of the organisation goals and objectives, this was also confirm by the result of the P-value obtained (i.e.0.000) which shows that that the value obtained was lower than the significance value of 5\% specified in SPSS for this analysis. 


\subsection{Conclusion}

The conclusion of this study is that effective internal control will significantly improve financial performance by helping the organisation to significantly reduce fraud perpetration. This was confirmed by the result of the statistical analysis which shows that that the P-value obtained (0.002) was lower than significance value of 5\% specified in SPSS for this analysis, Furthermore, the study also concluded that internal control contributes significantly to attainment of the organisation goals and objectives, this was because the P-value obtained (i.e.0.000) using regression analysis was lower than the significance value of 5\% specified in SPSS for this analysis. This means that for rapid improvement of organisation objectives, management of the organisation must discover new way of strengthening the internal control department.

\section{Recommendations}

The study recommends that management must develop and discover new ways to strengthen the internal control because the dimension of fraud in most organizations is growing at an alarming rate day by day, it further assert that this is necessary because both variable have significant relationship with each other. It also recommends that organisation can easily achieves its objectives, if the management of the organisation ensure a regular review and training of the internal control staffs so that each member of the internal control department is fully equip with the best skill to handle any unforeseen event that may hinder the organizational from achieving its objectives with the least possible resources.

\section{References}

[1]. Amudo, A. \&Inanga, E.L.(2009). Evaluation of Internal Control System, A Case Study from Uganda'International Research Journal of Finance and Economics,

[2]. Argryis, C(1990).Integrating the Individual and the Organization, Wiley, New York

[3]. Berle, A \& Means, G (1932) The Modern Corporation and Private Property," New York: MacMillan,

[4]. Boyo, B (1995). CEO Duality an Firm Performance in agency Model, StrategicManagement Journal, 16 (4), $301-312$. doi:10.1002/smj.4250160404

[5]. Cahill, E. (2006). Audit Committee and Internal Audit Effectiveness in a Multinational Bank: A case study. Journal of Banking Regulation 7,(1/2) 160 - 179.

[6]. Craig,D (2010). Australian Financial Accounting,(6th Eds). McGraw-Hill, New York, Caldwell,C\&Karri,R (1990). Organizational Governance and Ethical Choices: A Covenantal Approach to Building Trust," Journal of Business Ethics, 58, (1), 249-259. doi:10.1007/s10551-005-1419-2

[7]. Davis, J.H., Schoorman,F.D\& Donaldson, L(1997) Toward a Stewardship. Theory of Management Review, $22(1), 20-47$.

[8]. Donaldson,L\&Davis,L.H(1989). CEO Governance and Share holder,Annual Meeting of the Academy Management. Washington, 49-63.

[9]. Dittenhofer, M. (2001). Internal auditing effectiveness. Journal of Accounting And Economics, Vol. 5Donald K. K \&Delno L. A. T (2009) Proposal and Thesis Writing, An introduction.PaulinePublications Africa. Nairobi, Kenya.

[10]. Fama, E.F \&Jensen,M.C(1983). Separation of Owners and Control, Journal of Law and Economics, 26(2),301-325.

[11]. Freeman,R.E (2004). Strategic Management, Pitman, Boston.

[12]. Friedman \& Miles (2009) Stakeholders: Theory and Practice. Oxford: Oxford University press

[13]. Gerrit S and Mohammad J. A (2010), Monitoring effects of the internal Audit Function: Agency Theory versus other explanatory variables. International Journalof Auditing. Blackwell Publishing Ltd

[14]. Jensen, K. L. (2003), “A Basic Study of Agency-Cost Source and Municipal Use of Internal Versus External Control”, Accounting and Business Research, 35(4), 33-48.

[15]. Kirsch,L.J (2002). Developing Common System Globally: The Dynamics of Control Infrastructure, Information Systems Research Issue 15,154-167.

[16]. Kenya Sugar Board (2012). Sugar Board Strategic Plan 2004-2007,Nairobi.

[17]. Mawanda J. R (2008) The Relationship between Internal Control Systems and Financial Perfomance in Institutions of Higher Learning. Kampala.

[18]. Millichamp,A.H.(2005)..Auditing :An Instructional Manual for Accounting Students. London: Elbs-Df. Publication Ltd

[19]. Motubatse, K.N.(2005)..Internal Control Over Capital Assets of the Ekurhuleni Metropolitan Municipality.(M.Tech. Dissertation Submitted, Faculty of Economic Sciences, Tshwanel; University of Technology,South Africa:

[20]. Ouchi, W. G. (1979). A Conceptual Framework for the Design of Organizational Control MechanismsManagement Science. 833848

[21]. Rittenberg, L. E. \&Schwieger, B. J. (1997). Auditing: Concepts for a Changing environment, New York: The Dryden Press.

[22]. Simmons, M. R. (1997). COSO Based Auditing. Internal Auditor December: 68-73.Retrieved from: http://www.cwu.edu/ atkinson/coso.htm.

[23]. Shah. A. (2003) Local Public Financial Managemen

[24]. Suchman, M.C (1995). Managing Legitimacy: Strategic and Institutional approaches. The academy of management review, 20(3),571-610.

[25]. Transparency International(2006). Corruption Perceptions Index. Retrieved from:.http://www.transparency.org/policyresearch/ surveys. indices/cpi/2006

[26]. Williamson,O.E(1985). "The Economic Institutions of Capitalism: Firms, Markets, New York: Relation Press 